\title{
ASUHAN KEBIDANAN KOMPREHENSIF NY "L" DENGAN KEHAMILAN RISTI DI PUSKESMAS TOTOLI KABUPATEN MAJENE
}

\author{
Sastrariah $^{1)}$ \\ ${ }^{1)}$ Prodi Diploma Kebidanan STIKes Bina Bangsa, Majene, Sulawesi Barat \\ E-mail: sastrariah@yahoo.co.id
}

\begin{abstract}
Pregnancy risk is a bad situation in pregnancy that can affect the condition of the mother and fetus if carried out in general governance as is done in normal cases. The risk of pregnancy is deviating from normal, which directly causes pain and death of both mother and baby. The purpose of this study is to provide comprehensive midwifery care to Ny. L with a pregnant pregnancy in Totoli, Majene Regency. This research is a descriptive study with a case study approach. The population in this study were all pregnant women with cystic pregnancy in Totoli Health Center from January to March 2017, which were 19. The sampling technique used purposive sampling technique. Based on research shows that comprehensive midwifery care provided to $N y$. L starting during pregnancy, childbirth, childbirth and newborns make a positive contribution to the period of pregnancy, childbirth, childbirth and newborns. Prevents complications in the pregnancy pregnancy which can cause pain and death of mother and child. Assistance provided by midwives provides social support that motivates mothers with vaginal pregnancy to be passed normally. It is recommended that mothers should always consult with health workers and midwives must always improve their competence.
\end{abstract}

Keywords: Midwifery Care, Pregnancy High Risk

\begin{abstract}
Abstrak
Kehamilan risiko adalah keadaab buruk pada kehamilan yang dapat mempengaruhi keadaan ibu maupun janin apabila dilaksanakan tata laksana secara umum seperti yang dilakukan pada kasus normal. Risiko kehamilan merupak keadaan menyimpang dari normal, yang secara langsung menyebabkan kesakitan dan kematian ibu maupun bayi. Tujuan dari penelitian ini adalah untuk memberikan asuhan kebidanan komprehensif pada Ny. L dengan kehamilan risti di Totoli Kabupaten Majene. Penelitian ini penelitian ini adalah jenis penelitian deskriptif dengan pendekatan studi penelaah kasus (case study). Populasi dalam penelitian ini adalah seluruh ibu hamil dengan kehamilan risti di Puskesmas Totoli bulan Januari sampai dengan bulan Maret tahun 2017, yaitu sebanyak 19. Teknik pengambilan sampel menggunakan teknik purposive sampling. Berdasarkan penelitian menunjukkan bahwa asuhan kebidanan komprehensif yang diberikan pada $\mathrm{Ny}$. L mulai masa kehamilan, persalinan, nifas dan bayi baru lahir memberikan kontribusi positif terhadap masa kehamilan, persalinan, nifas dan bayi baru lahir. Mencegah terjadinya komplikasi pada kehamilan risti yang dapat meyebabka kesakitan dan kematian ibu maupun anak. Pendampingan yang dilakukan oleh bidan memberikan dukungan sosial yang memotivasi ibu dengan kehamilan risti dapat dilewati secara normal. Disarankan pada ibu sebaiknya selalu berkonsultasi kepada petugas kesehatan dan bidan harus selalu meningkatkan kompetensi yang dimiliki.
\end{abstract}

Kata kunci: Asuhan Kebidanan, Kehamilan Risti 


\section{PENDAHULUAN}

Kehamilan risti atau risiko tinggi adalah kehamilan dimana keadaan tersebut dapat mengganggu optimalisasi ibu maupun janin selama kehamilan. Ibu yang hamil dengan usia di atas 35 tahun sudah termasuk risti karena ada beberapa alasan. Umur $\geq 35$ tahun, pada usia tersebut mudah terjadi penurunan dari organ reproduksi ibu selain terjadi perubahan pada alat-alat kandungan. Ibu-ibu yang usianya lebih tua ( $\geq 35$ tahun) kehamilannya lebih mudah terserang diabetes gestational, preeklamsia dan tekanan darah tinggi serta resiko keguguran lebih tinggi. Resiko saat persalinan ialah lebih banyak yang melahirkan dengan sesar. Kelahiran bayi dengan usia ibu yang melebihi usia 35 tahun lebih besar kemungkinannya terjadi cacat kromosom, misalnya syndrom dan BBLR (WHO, 2014).

Peran bidan dalam menurunkan Angka kematian ibu adalah memberikan Asuhan Kebidanan kepada ibu hamil, bersalin dan nifas, melakukan pergerakan dan pembinaan peran serta masyarakat untuk mendukung upaya-upaya kesehatan ibu dan anak. Pelaksanaan berbagai program kesehatan sangat membutuhkan bidan yang berkompeten agar dapat tercapai tujuan. Bidan berperan penting sebagai ujung tombak karena merupakan tenaga kesehatan yang berhubungan langsung dengan wanita sebagai sasran program. Oleh sebab itu, bidan perlu senantiasa meningkatka kompetensi.

Grande multipara adalah Ibu pernah hamil atau melahirkan 4 kali atau lebih. Maka bahaya yang dapat terjadi antara lain persalinan letak lintang, kelainan letak, robekan rahim pada kelainan letak lintang, persalinan lama dan perdarahan pasca persalinan. Pada grandemulti juga bisa menyebabkan terjadinya solusio plasenta dan plasenta previa. Ibu hamil yang berumur 35 tahun atau lebih, dimana pada usia tersebut terjadi perubahan pada jaringan dan jalan lahir tidak lentur lagi. Selain itu ada kecenderungan akan didapatkan penyakit lain dalam tubuh ibu. Bahaya yang dapat terjadi yaitu tekanan darah tinggi dan preeklamsia, ketuban pecah dini, persalinan tidak lancar / macet dan perdarahan setelah bayilahir. Kehamilan di atas usia 40 itu berisiko melahirkan bayi yang cacat. Kecacatan yang paling umum adalah down syndrome (kelemahan motorik, IQ rendah) atau bisa juga cacat fisik. Pada ibu hamil dengan usia 40 tahun ke atas kebanyakan tidak kuat untuk mengejan karena nafas yang pendek. Akibatnya bayi bisa mengalami stres karena saat proses persalinan pembukaan mulut rahim akan terasa sulit (Prawirohardjo, 2010).

Semua ibu hamil diharapkan mendapatkan perawatan kehamilan oleh tenaga kesehatan. Untuk itu deteksi dini faktor risiko pada semua ibu hamil perlu dan perlu dilakukan skrining antenatal. Untuk itu periksa ibu hamil bisa dilakukan paling sedikit dilakukan empat kali selama kehamilan yaitu satu kali pada triwulan I (K1), satu kali pada Triwulan II, dan dua kali dalam triwulan III (K4). Berdasarkan jurnal (Retnaningtyas, 2018) bidan akan melakukan pemeriksaan klinis terhadap kondisi kehamilannya. Bidan akan memberi KIE (Komunikasi Informasi Edukasi) kepada ibu hamil, suamidan keluarganya tentang kondisi ibu hamil dan masalah yang terjadi.

\section{METODE PENELITIAN}

Jenis penelitian yang digunakan dalam penelitian ini adalah jenis penelitian deskriptif dengan pendekatan studi penelaah kasus (case study). Studi kasus yakni dengan cara meneliti suatu permasalahan yang berhubungan dengan kasus itu sendiri, faktor-faktor yang mempengaruhi, kejadian-kejadian khusus yang muncul sehubungan dengan kasus maupun tindakan dan reaksi kasus terhadap suatu perlakuan. 
Populasi dalam penelitian ini adalah seluruh ibu hamil yang termasuk kategori kehamilan risti tercatat di Puskesmas Totoli bulan Januari sampai dengan bulan Maret tahun 2017, yaitu sebanyak 19 kehamilan risti. Teknik pengambilan sampel menggunakan teknik purposive sampling. Kriteria inklusi yaitu bersedia jadi responden, berdomisili di wilayah kerja Puskesmas Totoli, ibu hamil yang usia kehamilannya 28-30 minggu, berkomunikasi dengan baik

\section{HASIL}

Pengkajian data dasar yang diperoleh oleh peneliti melalui anamneses, wawancara, dan pengkajian fisik yaitu Ny. L berusia 47 tahun dengan kehamilan keenam dan pernah keguguran satu kali. HPHT 02-07-2018, HTP 09-04-2019, Lila $27 \mathrm{~cm}$, TB $157 \mathrm{~cm}$, belum pernah suntik TT golongan darah A, jarak kehamilan terakhir dengan persalinan terakhir 13 tahun. Dari hasil pengumpulan data, maka ditegakkan diagnose GVI PIV AI, gestasi 30-32 minggu, PUKI, kepala, BAP, tunggal, hidup, keadaan ibu dan janin baik.

Intervensi atau rencana tindakan yang disusun berdasarkan diagnose yaitu sampaikan kepada ibu hasil pemeriksaan, beri support, mental dan spiritual pada ibu, diskusikan tentang persiapan persalinan seperti biaya, donor darah, kendaraan, tempat dan siapa yang akan menolong pada saat persalinan, sesuai dengan keinginan ibu, berikan ibu obat tablet $\mathrm{Fe}$, Calsium Laktat, B.Compleks, anjurkan ibu rajin datang kepuskesmas memeriksakan kehamilannya pada bulan berikutnya atau jika ada keluhan dan memberitahu ibu hal-hal yang perlu dihindari saat hamil serta resiko hamil diusia $>35$ tahun.

\section{PEMBAHASAN}

\section{Kehamilan (Antenatal Care)}

Pengumpulan data pada Ny. "L" didapatkan bahwa ini adalah kehamilan keenam, melahirkan 4 kali, dan pernah keguguran 1 kali, Umur Ny."L" 47 tahun, usia kehamilan 30 minggu. Dan menurut teori,beberapa keadaan yang dapat menyebabkan kondisi ibu hamil tidak sehat antara lain Empat Terlalu (terlalu muda $<20$ tahun, terlalu tua $>35$ tahun, terlalu dekat jarak kehamilan 2 tahun dan terlalu banyak anak) (Kemenkes kesehatan RI, 2015).

Kehamilan Resiko Tinggi (Resti) adalah kehamilan dimana keadaan tersebut dapat mengganggu optimalisasi ibu maupun janin selama kehamilan. Ibu yang hamil dengan usia di atas 35 tahun sudah termasuk Resti karena ada beberapa alasan. selain terjadi perubahan pada alat-alat kandungan, Ibu-ibu yang usianya lebih tua ( $\geq 35$ tahun) kehamilannya lebih mudah terserang diabetes gestational, pre-eklampsia dan tekanan darah tinggi serta resiko keguguran lebih tinggi(WHO. 2014).

Konseling yang diberikan pada saat kunjungan yakni, memberikan pemahaman kepada ibu tentang bahaya hamil di atas usia 35 tahun, menganjurkan ibu mengonsumsi Tablet Fe secara teratur, mengonsumsi makanan yang bergizi dan seimbang diantaranya makanan yang mengandung karbohidrat seperti nasi dan umbi-umbian, sumber zat besi berupa sayuran hijau seperti sayur bayam dan sayur kelor, sumber protein seperti ikan, telur dan daging serta ibu dianjurkan untuk tidak terlalu melakukan pekerjaan yang berat, menyarankan ibu untuk mempersiapkan persalinannya sedari dini dan segera ke pelayanan kesehatan jika terjadi hal-hal yang tidak di inginkan seperti keluar darah dari jalan lahir.

\section{Persalinan (Intranatal Care)}


Tanda-tanda inpartu adalah adanya rasa nyeri oleh adanya his yang datang lebih sering, kuat dan teratur, keluar lendir bercampur darah yang lebih banyak karena robekanrobekan kecil pada serviks, kadang-kadang ketuban pecah dengan sendirinya dan pada pemeriksaan dalam, serviks mendatar dan telah ada pembukaan (Mochtar, 2011).

Asuhan yang dilakukan pada Ny. "L" adalah memantau persalinan dengan menggunakan partograf, dengan pemeriksaan DJJ, nadi,dan his setiap 30 menit selama 10 menit. Selain itu dilakukan asuhan sayang ibu dengan menjelaskan hasil pemeriksaan, meminta keluarga untuk memberikan asupan nutrisi, membantu ibu untuk memilih posisi yang aman dan nyaman. Ibu merasa nyeri yang dirasakan semakin bertambah. Pukul 10:40 ketuban pecah kemudian dilakukan pemeriksaan dalam, pembukaan $10 \mathrm{~cm}$, vulva dan vagina normal, portio tipis, selaput ketuban pecah, persentase kepala, penurunan kepala 0/5, molase tidak ada, penumbungan tidak ada, kesan panggul normal, pelepasan lendir darah dan air ketuban jernih.

Pada Kala II berlangsung selama 25 menit dari pembukaan 10 sampai bayi lahir, proses pengeluaran bayi. Persalinan kala II adalah kala pengeluaran yang dimulai dari pembukaan lengkap sampai lahirnya bayi, berlangsung 2 jam pada Primi dan 1 jam pada Multi (Laili, 2014). Kala III pada Ny."L" berlangsung selama 5 menit yang dimulai dari lahirnya bayi pukul 11:05 wita hingga lahirnya plasenta. Kala III sering disebut dengan kala uri atau kala pelepasan plasenta yang dimulai dari lahirnya bayi sampai lahirnya plasenta yang berlangsung tidak lebih dari 30 menit (Mochtar, 2011).

Kala IV (2 jam masa nifas) pada Ny. "L" berlangsung normal, keadaan ibu dan bayi baik. Asuhan yang diberikan adalah melakukan pemeriksaan Tanda-tanda Vital, TFU, kontraksi uterus, kandung kemih dan perdarahan. Pemantauan kala IV dilakukan setiap 15 menit dalam 1 jam pertama dan 30 menit pada 1 jam berikutnya. Dan Menurut teori Kala IV ditetapkan sebagai waktu dua jam setelah plasenta lahir lengkap sampai 2 jam masa nifas, pemantauan Kala IV dilakukan setelah 15 menit lahirnya plasenta (Laili, 2014).

\section{Masa Nifas (Post Partum)}

Asuhan yang diberikan diantaranya menanyakan kondisi Ny."L" secara umum, melakukan pemeriksaan tanda-tanda vital, pemeriksaan lochia dan observasi perdarahan, pemeriksaan kontraksi rahim dan pemeriksaan tinggi tundus, menilai tanda-tanda infeksi, melakukan pemeriksaan payudara dan menganjurkan ibu memberikan ASI secara Eksklusif, serta memberikan nasihat kepada ibu untuk istirahat yang cukup dan mengonsumsi makanan yang bergizi dan seimbang. Kunjungan masa Nifas dilakukan sebanyak 4 kali kunjungan pertama dilakukan 6-8 jam setelah melahirkan dan kunjungan kedua dilakukan pada hari 3-6 hari masa nifas, kunjungan ke tiga di lakukan pada hari ke 7-14 masa nifas, kunjungan ke empat dilakukan pada hari ke 28 sampai 6 minggu masa nifas (Rukiyah, dkk. 2012).

\section{Asuhan Bayi Baru Lahir}

Asuhan berikutnya dilakukan IMD pada bayi selama kurang lebih 1 jam segera setelah bayi lahir. Menurut teori, pada Bayi Baru Lahir dilakukanIMD atau bayi menyusu sendiri sedari dini segera setelah lahir. Cara bayi melakukan inisiasi menyusu dini ini yakni merangkak mencari payudara ibunya dalam waktu kurang lebih 1 jam (Saifuddin AB, 2014). Kemudian setelah dilakukan pemeriksaan fisik bayi diberikan Vit. K $1 \mathrm{mg}$. Menurut teori, semua bayi lahir diberikan Vit.K $1 \mathrm{mg}$ secara intramuskuler di paha kiri agar dapat mencegah perdarahan pada bayi baru lahir(Syaifuddin AB, 2014). Setelah IMD dan disuntikkan Vitamin K1, Asuhan selanjutnya yaitu bayi diberikan Imunisasi Hepatitis B 2 jam setelah bayi lahir. 
Dan menurut teori, Imunisasi Hepatitis B pertama diberikan di usia 0 hari yaitu 2 jam sampai tujuh hari setelah bayi lahir (Saifuddin AB, 2014).

\section{Asuhan Neonatus}

Asuhan yang diberikan yaitu melakukan pemeriksaan tanda-tanda vital pada bayi, menganjurkan ibu agar tetap menjaga kehangat bayi, mengganti pakaian bayi setiap kali kotor atau basah, mengajarkan ibu untuk merawat tali pusat, serta tetap memberikan ASI secara Eksklusif pada bayi.kunjungan kedua dilakukanpada hari ke tiga, asuhan yang diberikan yaitu melakukan pemeriksaan TTV dan tanda-tanda infeksi pada bayi, menjelaskan pada ibu pentingnya memberikan imunisasi lengkap pada bayinya, menganjurkan pada ibu untuk segera membawa bayinya ke pelayanan kesehatan jika bayi mengalami demam, rewel dan tidak mau menyusu.

\section{KESIMPILAN DAN SARAN}

Kesimpulan penelitian asuhan kebidanan Ny. "L" dengan kehamilan risti di Puskesmas Totoli Kabupaten Majene adalah Asuhan yang telah diberikan pada Ny. "L" dan bayi Ny. "L" dapat diperoleh kehamilan dengan masalah ibu hamil usia 47 tahun Grande Multipara. Dalam kasus ini persalinan Ny. "L" berlangsung normal dan tidak ada penyulit, bayi Ny. "L" dalam keadaan sehat dan tidak ada kelainan, serta masa nifas berlangsung normal dan tidak ada penyulit.

Penulis menyarankan kepada Pemerintah/ puskesmas sarana dan prasarana kesehatan dalam pelayanan tingkat dasar. Bagi ibu hamil, sebaiknya sering berkonsultasi dengan petugas kesehatan. Tenaga kesehatan yang professional sebaiknya selalu mengikuti ilmu-ilmu terbaru melalui studi dan pelatihan sehingga dapat menjadi tenaga kesehatan yang professional dan kompeten dalam memberikan pelayanan.

\section{DAFTAR PUSTAKA}

Bieri FA, Gray DJ, Williams GM, Raso G, Li Y-S, Yuan L, et al. Health-Education Pacage to Prevent Worm Infections in Chinese Schoolchildren. $\mathrm{N}$ Engl J Med. 2013;2(1):29.

Dien Gusta AN. (2015). Kehamilan Risiko Tinggi di Puskesmas Lubuk Gadang Kabupaten Solok Selatan. Jurnal Kesehatan Masyarakat Andalas. http://jurnal.fkm.unand.ac.id/index.php/jkma/article/download/414/241

Kemenkes, RI. 2010. Profil Kesehatan Indonesia 2010. Jakarta

Laili, dkk.2014. Hubungan Faktor Risiko Kegawatdaruratan Obstetri menurut Rochjati dengan Pelaksanaan Rujukan oleh Bidan di RSUD Gambiran Kediri .(ejournal: http://ijemc.unpad.ac.id/ijemc/article/view/11

Mochtar. 2011. Sinopsis Obstetri Edisi 3. Jakarta: EGC

Notoatmodjo S. 2010. Promosi Kesehatan dan Ilmu Perilaku. Jakarta: Rineka Cita

Puskesmas Totoli (2017). Data Ibu Hamil dengan Kehamilan Risiko Tinggi 
Prawirohadjo. 2010. Ilmu Kebidanan. Jakarta: YBPSP

Rochjati, P. 2011. Skrining Antenatal pada Ibu Hamil Edisi 2. Jakarta: Salemba Medika

Riskesdas. 2013. Kehamilan Beresiko

Saifuddin. 2014. Buku Acuan Nasional Pelayanan Kesehatan Maternal dan Neonatal. Jakarta: YBPSP 